\title{
An Overview of Natural Gas as an Energy Source for Various Purposes
}

\author{
Cenker Aktemur $* *$ \\ * Department of Mechanical Engineering, Eastern Mediterranean University, G. Magosa, North Cyprus, via Mersin 10, Turkey \\ (cenkeraktemur_41@hotmail.com)
}

\begin{abstract}
¥Corresponding Author; Cenker Aktemur, Department of Mechanical Engineering, Eastern Mediterranean University, G. Magosa, North Cyprus, via Mersin 10, Turkey, Tel: +90 538266 0367, cenkeraktemur_41 @ hotmail.com
\end{abstract}

Received: 26.03.2017 Accepted: 03.09.2017

\begin{abstract}
Energy is gaining great prominence and priority regarding improvement the level of prosperity by completing the economic development of countries. Natural gas is becoming one of the most important energy sources in the world because of the low level of greenhouse gas emissions resulting from the burning of natural gas. For that reason, natural gas consumption is increasing rapidly in the world. Natural gas, which is the main raw material of various chemical products, meets a significant part of the world energy consumption. It is an obvious fact that natural gas is the second most considerable non-renewable fossil fuel-based energy source, after crude oil. This study deals with reviewing natural gas systems considering each aspect. In this context, natural gas as an energy source along with its historical development was briefly given first. Then, status of world natural gas market with regard to geographical distribution of natural gas reserves, consumption, production, lifetime and storage are investigated in all parts of the world. After this exploration of natural gas as primary energy source, pollution caused by natural gas is reviewed since it is utilized in many areas like residential buildings, vehicles and industry. Beside all these, available pipelines delivering natural gas to consumers and planned pipeline projects to be constructed in the near future are reported. Lastly, the use of liquefied natural gas and compressed natural gas as alternative energy source are discussed.
\end{abstract}

Keywords Natural gas, non-renewable energy, primary energy, fossil fuel.

\section{Introduction}

Energy is a factor that cannot be ignored in the social and economic development of countries and, therefore, in increasing social welfare, continues to be a considerable issue in all parts of the world. It is extremely noteworthy to obtain energy from continuous, cheap, reliable and clean sources and to utilize it efficiently.

Natural gas is a gas in the fossil-derived gas class which consists of methane gas in large quantities, under the pressure and temperature transformation between the ground layers of the living things of our world living millions of years ago. It is also called $\mathrm{H}$ type petroleum gas. Like petroleum, it is found in underground layers in nature. It is made up of methane, less ethane, propane, butane, nitrogen and carbon dioxide gases. Natural gas is a gas mixture of paraffin, carbon, hydrogen in the gaseous state and their percentages depend on the source of the natural gas.

\section{Historical development of natural gas}

The history of natural gas, which is one of the biggest energy sources of our era, dates back hundreds of years. Statement of the "Sacred Fire" has been used throughout the humanity history. Sanctuaries established before Christianity have retained their importance for centuries in a variety of areas where the gas flames are existed in Azerbaijan. For the first time, natural gas as an energy source was employed for drying salt by Chinese in the reign of Shu Han, after the birth of Chris. In recent history, Chinese have tried to transport natural gas to other places by means of hollowed bamboos.

In Europe, the first natural gas was found in the UK in 1659. There are some documents which shows that natural gas was used for lighting and heating purposes by Northern Italians in this century. Alessandro Volta, who was known especially as a battery finder, declared natural gas as "Flaming Air of Swamps" in 1776. An Italian scientist, Lazzaro Spallanzani, termed as "Natural Gas" in 1795, was 
inspired by the gas term created by a Dutch scientist, Jan Baptista Van Helmont, in 1609.

The lighting of the streets and houses benefited largely from natural gas. The first discovery of gas fields was in the vicinity of a salt mine in Charleston city of the U.S. state of West Virginia in 1815. In the following five years, the first commercial gas operations were conducted in state of New York in 1820 by William Hart.

The transportation of natural gas for commercial purposes to a long-distance place was implemented when it is transported to Pittsburgh through pipelines. The total length of pipelines for natural gas distribution reached about $750 \mathrm{~km}$ in the same city. On the same date, the total length of other transmission lines within The United States of America borders was just about $40,000 \mathrm{~km}$.

Until Second World War (also known as World War II), natural gas technology was not almost available in the countries outside of the United States. Afterwards, production and consumption of natural gas became widespread with the discovery of prominent sources in Pakistan, the Soviet Union, and North Africa. After the Second World War, there were even more advancements in the production of pipes as well as welding technology, and this led to a significant enhancement in the volume of natural gas transported in the course of time. Canada had an immense amount of natural gas, some of which was exported to America owing to excessive need for natural gas use. In Russia, the gas produced by developing natural gas field was initially shipped to Central Asia, Northern European Russia, and Eastern European countries.

In the mid-1900s, Germany, Italy, France, and Austria were utilizing their existing natural gas potentials. With improvement of the Groningen field in the Netherlands, some potentials here were exported to neighboring countries in 1959. Germany was linked to Groningen gas system in 1964. However, when it comes to rising irretrievable energy demand from internal sources and neighboring countries, natural gas as liquefied was transported by tanker from Algeria, Libya, Brunei, Nigeria, and especially Middle East. In this manner, Japan and the United States of America carried out the transfer of the energy on a vast scale. Natural gas was connected to the system of Western Europe by the Soviet Russia based on the condition that it would start from Germany in 1974 [1].

The first natural gas was detected in Kirklareli / Turkey in 1970. After 6 years, it was utilized at a cement plant in Kirklareli, which was operated under Set Cement Industry and Trade Joint Stock Company. Petroleum Pipeline Corporation (BOTAS in Turkish initials), which will play a very important role in the Turkey natural gas market in the coming years, was established by Turkey Petroleum Corporation (TPAO) in 1974. Natural gas found in the muddy pitch in 1975 was allocated to Mardin Cement Plant in 1982. Electricity generation using natural gas was carried out with domestic sources at Hamitabat Combined Cycle Power Plant in 1985.
When the history of the studies related to natural gas is painstakingly examined in Turkey, it is seen that the first studies pertaining to this topic were the research on "Natural Gas Demand and Supply" carried out by the General Directorate of BOTAS in 1983. This work was carried out with signing of a framework agreement by the Soviet Union with respect to natural gas purchased in 1984. Within 2 years following this agreement, commercial agreement was signed by BOTAS and Sovyet Soyuz Eksport for a 25-year on natural gas imports, which was expected to reach 5 to $6 \mathrm{bcm}$ / year in the 1990s.

This first initiative for the supply of natural gas was made in order to ensure that imports can be carried out effectively. The construction of $842 \mathrm{~km}$ long pipeline starts from Malkoclar on Bulgarian border, and then reaches Gemlik-Bursa, Bozuyuk-Eskisehir through Ankara. By the fall of 1988, natural gas was operationalized for the potential use of settlements unit on the route. Along with the construction of this main line, international tenders were launched by the General Directorate of EGO and IGDAS for the construction of natural gas networks among these cities in 1988.

Natural gas was used for the first time in Turkey in residential and commercial sectors in Ankara in October 1988, in Istanbul in January 1992, in Bursa in December 1992, in Izmit in September 1996 and in Eskisehir in October 1996 [2].

\section{An outlook of the world natural gas market}

Natural gas consumption, which was more local in the 1950s and met only $10 \%$ of the world's energy consumption, increased steadily in the following years. The oil crisis that emerged in the 1970s adversely affected the economies and air pollution caused by augmented consumption of coal due to crisis, was one of the most important reasons of this increase. Moreover, the fact that natural gas is cleaner than other fossil fuels has led to an augmentation in its share in international trade.

According to the study done by the International Energy Agency (IEA), it was estimated that world natural gas consumption, which is advanced by an average of $2.1 \%$ every year, reached $3.68 \mathrm{tcm}$ in 2015 and would reach 4.78 tcm in 2030. Until 2035, it is anticipated that natural gas will be the only fossil fuel whose proportion will go up in global energy sources. For this reason, natural gas production will boost in all regions except Europe.

In accordance with the New Policy Scenario, world gas demand will reach $4.75 \mathrm{tcm}$ in 2035 and global natural gas consumption is expected to be at the same level with coal consumption in the same year. It was also assumed that $81 \%$ of the increase in natural gas demand would stem from nonOECD (Organization for Economic Co-operation and Development) countries [3]. 


\subsection{World natural gas reserves and geographical distribution}

With the commencement of pipeline transport, natural gas has become prevalent in the creation of the increasing energy demand together with evolving technology, and undertaking examinations to reduce reliance on oil as a result of the oil crises experienced throughout the world.

Natural gas reserves have climbed by nearly $56 \%$ in the last two decades. The amount of natural gas reserves, which was $119.9 \mathrm{tcm}$ by the end of 1995, increased in $157.3 \mathrm{tcm}$ in 2005 and $186.9 \mathrm{tcm}$ in 2015. While Europe \& Eurasia and Middle Eastern countries accounted for $43.4 \%$ and $30.2 \%$ of the world natural gas reserves in 1990, respectively, the share of Europe \& Eurasia reserves diminished by $30.4 \%$ and the Middle East reserves ascended by $42.8 \%$ in 2015 (see Fig. 1). Russian Federation, which ranked first with its proven reserves of $32.3 \mathrm{tcm}$ in 2015 , is followed by Iran with $34 \mathrm{tcm}$ and Qatar with $24.5 \mathrm{tcm}$. The total natural gas reserve of Turkmenistan, which has the largest natural gas reserves and annual production capacity among the Central Asian Republics, is around 17.5 tcm (see Fig. 2).

Today, many producers and consumers are emerging and the share of natural gas in total energy consumption is increasing by slow degrees. As the day goes on, natural gas is expected to meet $21 \%$ of the world's total energy consumption. It is thought to meet approximately $25-30 \%$ in 2030 provided that the technological developments keep going. In addition, it is expected that its share in international trade will develop significantly as it is cleaner than other fuels. When the developments in the international energy market since 1980 are examined, the following three basic factors come to light [4].

- Instead of the traditional oil and gas companies, all of the companies, including the major oil companies, have become an energy company,

- From 2005 onwards, there has been a thought in the world energy consumption that natural gas will get more share rather than oil,

- Instead of purchase and sale in the classic sense of natural gas trade to ensure the safety of the source, the sale is carried out through the sale of the reserve in the production field.

\subsubsection{World natural gas reserve lifetime}

The natural gas production went down due to the economic crisis experienced in 2009. For that reason, natural gas reserve life increased and the reserve life of 2009 become 62.7 year. Reserves-to-production $(\mathrm{R} / \mathrm{P})$ ratios are calculated with the total current reserve $(186.9 \mathrm{tcm})$ divided by the total current production $(3.538 \mathrm{tcm})$; thus, the global reserve life was estimated to be 52.8 years. It is predicted that the US, which has the highest share in world natural gas production, has a reserve life of less than 20 years. However, it is estimated that non-traditional sources of natural gas, which have been produced since the last 10 years in the US, will extend the reserve life up to 200 years. In the context of the 52.8-year "natural gas reserve life", which is defined in general terms, is the life of the reserves that have been proven to be today's economical production of existing conventional technologies. Approximately half of the reserves of the European Union are made up of the reserves of the Netherlands. It was foreseen that 4.5 years of reserves would remain if the UK continues with its current production $[6,7]$.

\subsubsection{World natural gas production}

World natural gas production, which was $3463.2 \mathrm{bcm}$ in 2014 , increased by $2.2 \%(3538.6 \mathrm{bcm})$ in 2015 . While natural gas production dropped by $1.5 \%$ in Russian Federation, it rose by $5.4 \%$ in the US, $16.4 \%$ in Myanmar and $5.7 \%$ in Iran. The United States proceeded to be the world's largest natural gas producer with $763.7 \mathrm{bcm}$. The regions that have the highest increment in natural gas production in 2015 are the Middle East (45.2 \%), Asia Pacific (22.6\%) and North America (21.3) [5]. Top 10 countries having the highest total of share in these regions are shown in Fig. 3.

\subsubsection{World natural gas consumption}

From 1965 to 2015, the use of fossil fuels sustained to grow remarkably and share of energy supply enhanced. Since then, natural gas has been adopted by regions and found itself an important place among fossil fuels even though the consumption quantities have decreased from time to time. The constant increase in natural gas consumption between 2005 and 2008 was followed by a steady increase in the following years after a decline in 2009. Provided that the economic crisis which took place in 2009 is ignored, world natural gas consumption increased by $4.7 \%$ (3051.2 to $3201.4 \mathrm{bcm}$ ) when compared to 2008 and 2010 natural gas consumption.

Asia Pacific (20.1\%), North America (28.1\%) and Europe \& Eurasia $(28.8 \%)$ are regions which witnessed the highest increase in consumption in 2015. From the beginning of 2009 until 2015, natural gas consumption in the US, which is the world's largest natural gas consumer, increased by $20 \%(129.3 \mathrm{bcm})$ whereas natural gas consumption in Russian Federation, which is the world's second largest natural gas consumer, rose nearly by $0.5 \%$ (1.9 bcm). Although consumption in the Europea \& Eurasia region, which also includes Turkey, increased by $10 \%(3.3 \mathrm{bcm})$ in 2010 compared to 2009, this consumption amount in 2015 was observed to be lower than consumption amount in 2014. From the beginning of 1965 onwards, natural gas consumption amounts by years are illustrated in Fig. 4. 


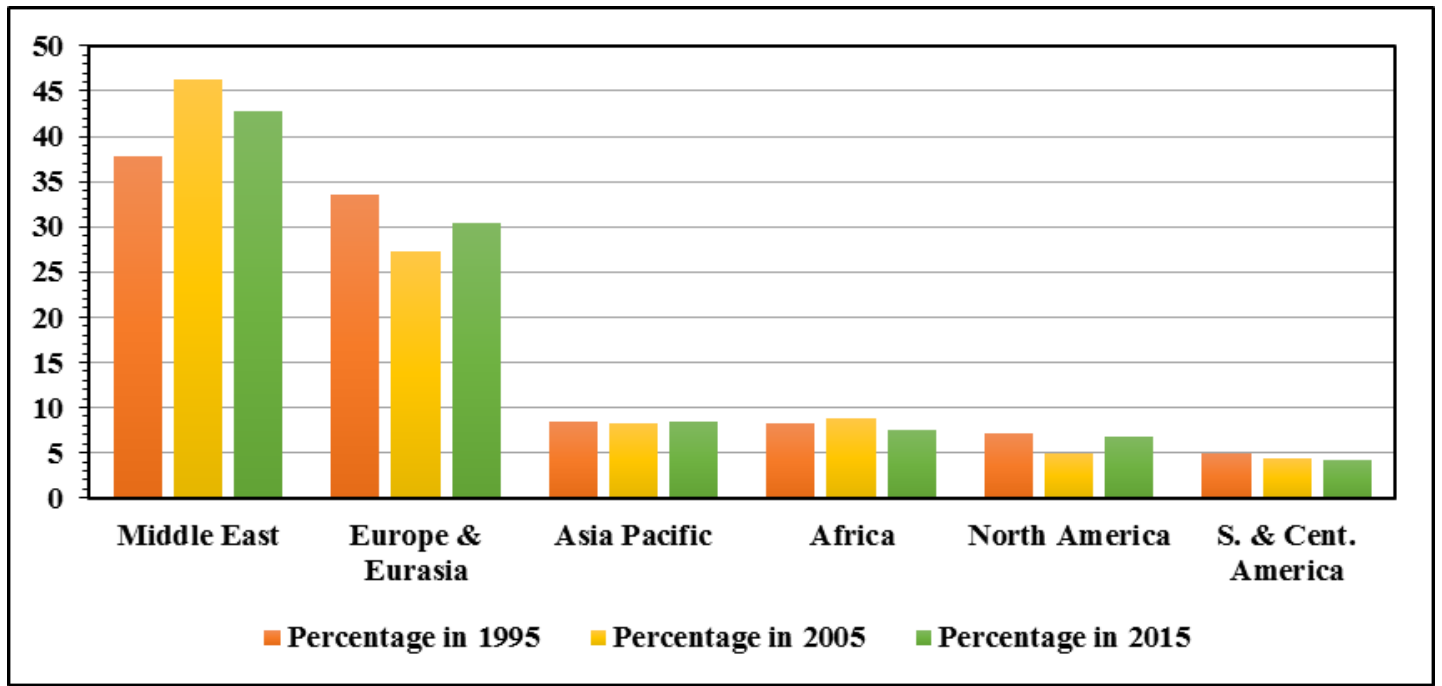

Fig. 1. Distribution of proved natural gas reserves by regions [5].

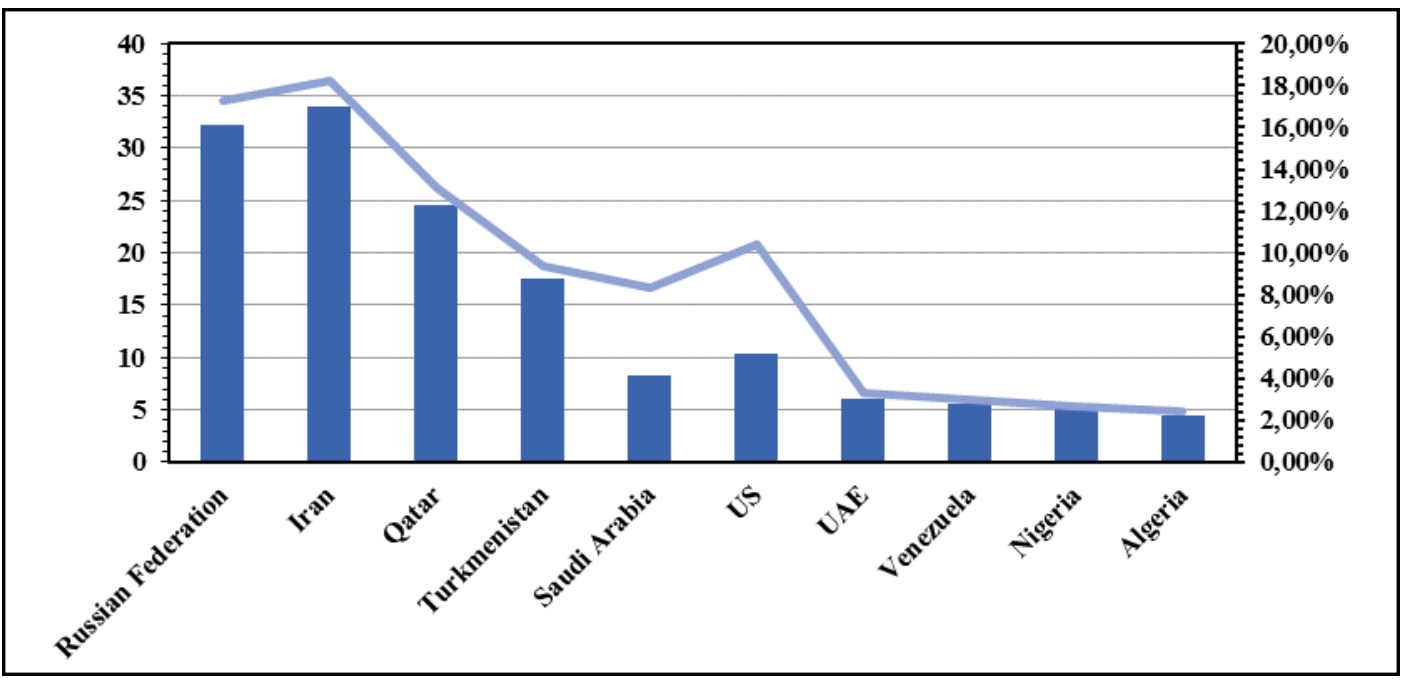

Fig. 2. World proven gas reverves and share of total by 10 countries (tcm) [5].

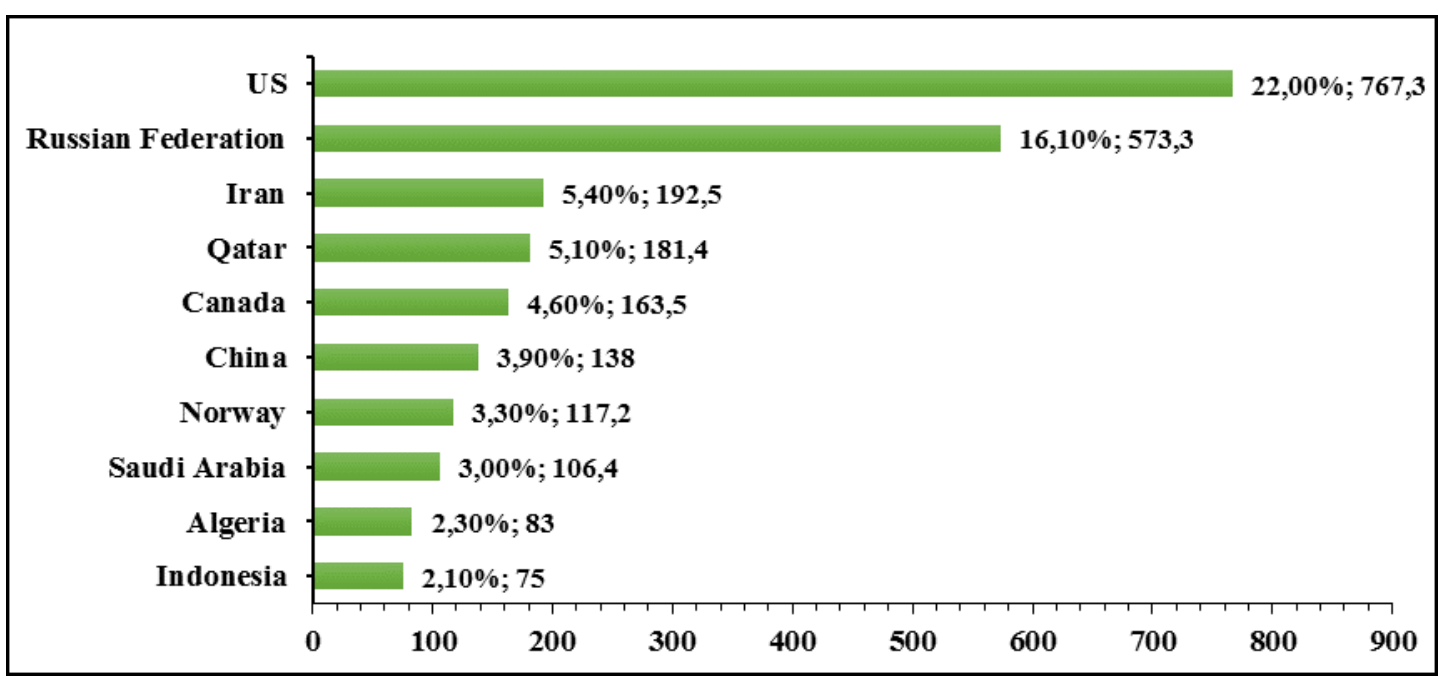

Fig. 3. World natural gas production by ten countries (bcm) [5]. 


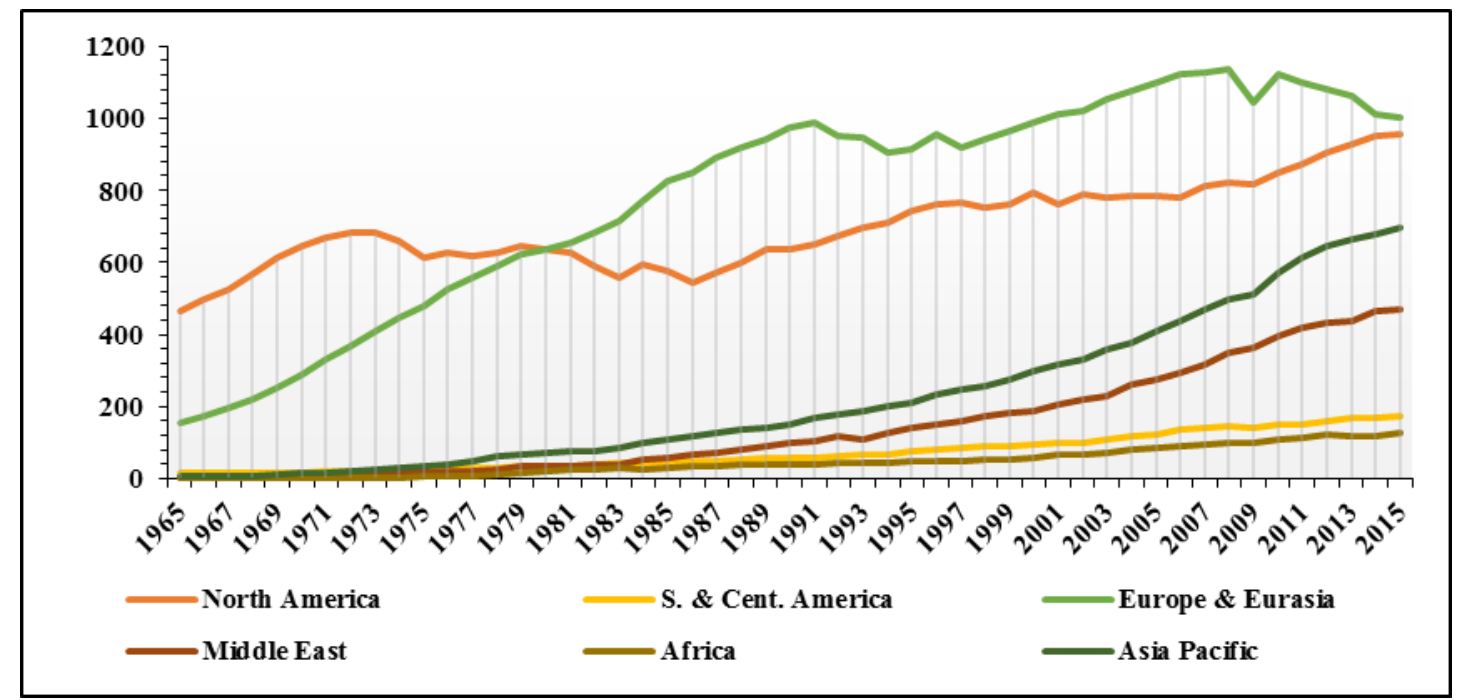

Figure 4. World natural gas consumption by years (bcm) [5].

As depicted in Fig. 4 above, it can be inferred that developed countries consume more natural gas. Developed countries in North America, Europe and Asia regions make up about $80 \%$ of the world consumption. The fact that natural gas is a clean fuel, portable and easy to use can be shown as evidence among the reasons for the increase in consumption in these regions.

According to the New Policy Scenario involving IEA's determination in 2011, it is estimated that China's demand for natural gas consumption will rise from $197.3 \mathrm{bcm}$ in 2015 to $500 \mathrm{bcm}$ in 2035 . In the light of IEA's determination in 2011 , it is pointed out that the world's largest natural gas producer will be Russia's rising natural gas producer with $860 \mathrm{bcm}$ per year and North American natural gas supplydemand will be in balance in 2035 [8].

According to the data in Figure 1, 2, 3 and 4;

- As of 2015, Russian Federation and Iran, which have the largest reserves of natural gas, have roughly $1 / 3$ of the world natural gas reserves.

- The sum of reserves of the Middle East and Europe\&Eurasia regions make up almost $75 \%$ of the world natural gas reserves.

- Iran and Qatar in the Middle East, and Russia in Europe\&Eurasia are the countries that have the largest reserves of natural gas.

- The total amount of reserves that Iran and Qatar have account for nearly $31 \%$ of total Middle East (42.8\%).

- Around $43 \%$ of the world natural gas production is supplied by Russian Federation, Iran and US.

- While North America region, which has an important share in world natural gas production, is the fifth considering the reserve amount.

\subsubsection{Natural gas storage}

In the world, underground gas storage was carried out for the first time in a depleted gas reservoir in Canada in 1915, followed by experiments made in New York in 1916 and in Kentucky in 1919. Storage technology between variable demand and fixed supply in natural gas sector, from 1917 to present day, continued to thrive incessantly.

While the total volume of underground natural gas storage working gas capacity was $328 \mathrm{bcm}$ in the world in 2000 , it was recorded as $270.6 \mathrm{bcm}$ by the end of 2014 . North America has $70 \%$ of world storage facilities with 452 storage facilities, including 402 in the US and 50 in Canada. With the liberalization of natural gas markets and the shortterm trade of natural gas, it is hoped that the demand for natural gas storage will increase [9].

Iran, which is one of the largest natural gas producers in the world, operated the first underground natural gas storage facility in the Middle East with the completion of the project carried out by the Iranian Natural Gas Storage Company (NGSC) in May 2011 so that natural gas exports could continue uninterruptedly during the winter months. The first step was to expand its capacity from 7.3-9 to 30 million cubic meter.

Immediately after the establishment of the "Underground Storage Coordinatorship" unit within BOTAS in 1988, underground natural gas storage and the reserves of Turkey investigated in order to enable gas storage from the Russian Federation in Turkey. At the end of these examinations salt masses situated in the South of Salt Lake and Northern Marmara gas field were found suitable for use as a warehouse. Silivri natural gas storage facility, which is the only warehouse currently in operation in Turkey, was operated by TPAO and has a total capacity of $2.6 \mathrm{bcm}$. After completion of additional capacity-building facilities, an excess of $4 \mathrm{bcm}$ of natural gas will be stored in Silivri. It is anticipated that Salt Lake natural gas storage where the 
investments are made by Chinese Tianchen Engineering Company will be put into service in 2019 [10].

\section{Effects of natural gas on air pollution}

In all cities of the world, fossil-based energy sources are being used extensively, either directly or by converting to electricity, in the face of the majority of energy needs. The production and use of fossil-derived energy brings many negative effects on human and environmental health. Air pollution caused by burning varies depending on the amount of fuel burned, the fuel pollution and combustion characteristics, combustion systems and operating conditions, pollutant emissions to atmosphere, and topographic and meteorological conditions.

The most common air pollutants around the city are sulfur dioxide $\left(\mathrm{SO}_{2}\right)$, nitrogen oxides $\left(\mathrm{NO}\right.$ or $\mathrm{NO}_{2}$, often called $\mathrm{NOx})$, carbon monoxide $(\mathrm{CO})$, ozone $\left(\mathrm{O}_{3}\right)$, particulate matter $(\mathrm{PM})$ and lead $(\mathrm{Pb}) . \mathrm{CO}_{2}$ emissions are the inevitable product of combustion technology based on the use of fossil fuels, and the amount of $\mathrm{CO}_{2}$ in the atmosphere increased just about 1.3 times in the last century. In the next 50 years, this amount is likely to increase by 1.4 times. The greenhouse effect caused by $\mathrm{CO}_{2}$ in the atmosphere enhanced the world average temperature by $0.7{ }^{\circ} \mathrm{C}$ over the last century. Particularly in developing regions, pollution has been increasing along with the increase of urbanization and energy consumption.

In turkey the need for heating is supplied by coal, petroleum-based fuels, natural gas, and geothermal sources. While the most consumed energy source is coal, natural gas agreements and investments has been made in recent years and natural gas have begun to be used to meet the significant heating needs. Also, natural gas has been exploited in order to overcome the air pollution arising from intensive urbanization.

Natural gas is a fuel that does not pollute the environment compared to other fuels. The three main polluting factors $\left(\mathrm{SO}_{2}, \mathrm{PM}\right.$ and smut $)$ are not found in natural gas fumes. One of the most important features of natural gas is that it is nontoxic. There is no poisonous and lethal effect in case of natural gas inhalation. However, if there is too much accumulation in the environment, there is a danger of suffocation due to the reduction in oxygen to be inhaled. If the combustion product gases are emitted to the atmosphere, they may poison due to the increase of $\mathrm{CO}$ as in other fuels. For this reason, the use of natural gas instead of coal in heating significantly reduces harmful gas emissions $[11,12]$.

As a result of combustion of natural gas which is a cleaner fuel than other fuels due to the emission of pollutants resulting from combustion, $\mathrm{CO}_{2}, \mathrm{CO}$ and $\mathrm{NO}_{\mathrm{X}}$ are formed. There is no sulfur oxides in it because it does not contain sulfur. It is also an important advantage that it does not form soot and flying ash particles as seen from above table. The lack of carbon monoxide formation, which is described as unburned gas and which is an extremely harmful gas, is another advantage compared to other fuels. $\mathrm{NO}_{\mathrm{X}}$ is another component of combustion products that is harmful to the environment. One of the main reasons for the formation of nitrogen oxides is the high combustion temperature [13].

\section{Usage areas of natural gas}

The most widely used area of natural gas is energy production area. In addition to ensuring energy demand for natural gas in industrial and residential use, it is also used in cooling systems as well as for improving the performance of the system in thermal power plants, providing better emission values and as a raw material in the industrial sector [14]. Furthermore, natural gas has been utilized an engine fuel in the world. Natural gas motor vehicles that are used in Turkey in recent years are more prevalent.

Around the world, specifically in the 80 's, the number of natural gas-producing power plants is increasing due to the fact that natural gas is an environmentally friendly and efficient fuel. It is used in two main forms of electricity generation. According to this, electricity can be produced by turning the steam turbines of water vapor obtained as a result of incineration of natural gas or burning natural gas directly into gas turbines [15]. The reason why natural gas is preferred in electricity generation is the fact that it is more efficient and cost-effective than other sources. According to the UEA's World Energy Outlook 2010 report, the use of natural gas in electricity generation will rise $33 \%$ from 2007 to 2035 [16].

Natural gas is also used in white goods painting, adhesive industry, artificial rubber cutting of metals in industry, heavy industry, making ceramics in ink industry, and obtaining antifreeze.

\subsection{Use of natural gas in residential buildings}

Energy is a value that is considered to be indispensable for countries that make up the basic input of the social, economic and industrial development of each country. The main objective of countries of the world is to use natural gas in a cost-effective and environmentally friendly manner since natural gas meets a significant proportion of the world's main energy needs. Different factors in the choice of heating systems for buildings can be decisive on the grounds that urbanization and rapid population growth are experienced intensively. These factors include the purpose of the use of the building, the periods of the use of the parts in the building, available and usable fuel types, and the budget of the project.

Alternative heating systems should be considered in order to find a suitable solution for each building in terms of heating technology, economy and environment, and these should be carefully considered. In general, different heating methods may apply to the same building. For example, in residences, central and individual heating systems can be preferred [17]. 


\subsection{Use of natural gas in vehicles}

The spread of natural gas as an alternative fuel with low emissions compared to gasoline and diesel vehicles is particularly noticeable in recent years. In spite of the fact that natural gas has rich sources, and has become widespread through the use of pipelines in many countries, the use of natural gas as a fuel in vehicles was slow compared to other applications. The rapid increase in the number of vehicles preventing environmental pollution has become difficult. That is why, European Union countries attach importance to the use of alternative fuels and reduction of emissions on vehicles. In this regard, the use of natural gas is as important as the use of alternative fuels. The studies on natural gas is supported by International Association for Natural Gas Vehicles (IANGV) and European Natural Gas Vehicles Association (ENGVA) institutions, which are known to be leading institutions [18-22].

Detailed studies and research are being conducted for the use of compressed natural gas (CNG) on vehicles in many western countries as it is thought to be an environmentally friendly alternative fuel with low emission amounts. For the sake of giving an example, it is necessary to examine the US, where the greatest number of road transport vehicles are utilized in the world. There are 520 million cars and trucks in the world, 190 million of which are found in this country. It has been determined that an average $50 \%$ of air pollution in the US is caused by exhaust stemming from these vehicles. In order to reduce exhaust emissions in these oil-dependent vehicles, catalytic filters were installed on all gasoline vehicles in the US where various measures were taken, the engine designs of the vehicles were improved, and the gasoline and diesel fuel structures were altered. Since these precautions are not sufficient, The Clean Air Act and The Energy Law, which were adopted in 1990 and 1992, respectively, initiated investigations for alternative fuels [2325].

Iran is in the forefront in terms of natural gas-powered vehicles, followed by China, Pakistan, and Argentina. The top 10 countries by the number of natural gas-powered vehicles throughout the world are given in Fig. 5. Iran and Argentina are playing leading role in Asia-Pacific and S. \& Cent., respectively. The International Association for Natural Gas Vehicles (IANGV) predicted that there would be 65 million natural gas vehicles in all parts of the world in 2020 [26].

For the first time in Turkey, natural gas vehicles produced in TOFAS are exported to many European countries. Doblo and Fiorino, called "Natural Power", are successful examples of natural gas-powered vehicles. With the market which has been created under the leadership of Naturelgaz, as of 2012, the conversion of vehicles to natural gas has begun. CNG conversion systems can be applied to all vehicles including trucks, tractors, trucks, buses, light commercial vehicles and passenger cars. In addition, many leading vehicle manufacturers such as Iveco, Mercedes, MAN, Scania and Volvo have CNG vehicles.
New natural gas-powered buses were used in order to reduce air pollution and fuel costs caused by exhaust gases in public transportation in Kocaeli, Ankara, Kayseri and Istanbul providences, Turkey. Kocaeli Metropolitan Municipality saved about $20 \%$ for 2010 with 45 natural gas buses that were actively commissioned in December 2009 [27].

\subsection{Use of Natural Gas in Industry}

The use of natural gas, which is easier to obtain than other energy sources and has a lower impact on the environment, is increasingly being used as a primary energy source in the world. Due to the advantages such as high efficiency and short time operation, natural gas-fired combined cycle power plants have been utilizing increasingly in recent years in electric energy production in the world [28].

Gas turbines and steam turbines are used together in combined cycle power plants. In addition to the electric energy obtained from gas turbines using natural gas as fuel, steam generated from the waste heat of the exhaust gases with high temperature from the turbine exhaust and steam turbines provide additional electricity generation. In these plants, combined cycle efficiency can be realized at around $60 \%$ by combining the advantages of high temperature of gas turbine cycles and low temperature of steam turbine cycles. Natural gas-fired combined cycle thermal power plants can be operated in a shorter period of time with lower installation costs than thermal, nuclear and hydroelectric power plants using other fossil-based fuels [29].

Hence, the use of natural gas in electricity increased and now $55 \%$ of the imported natural gas is being used in electricity. At the moment, $45 \%$ of the total electric energy production are obtained from natural gas power plants. The total installed capacity of 277 Natural Gas Power Plants located in Turkey is 22,584.60 MW. In 2015, 98.326.026.435 kilowatthours of electricity were produced in natural gas power plants [30].

\section{Natural gas pipeline transportation}

Transportation of natural gas commenced with smallscale and short-haul routes in the late 19th century. A longdistance transportation of natural gas was brought to Pittsburgh in commercial for the first time in 1883 by way of pipelines. Until the Second World War, natural gas technology was not very common in countries outside the US. After the Second World War, developments in pipe manufacturing and welding technology have resulted in a significant increase in the volume of natural gas transported by allowing pipeline pressures of 25-30 bar to be increased to 60-70 bar and pipeline diameters up to $75 \mathrm{~cm}$. Today, in the international arena, natural gas pipelines can reach up to 150 $\mathrm{cm}$ in diameter. In order to facilitate the transportation of natural gas, $R \& D$ studies have been continuing in the world and to increase the applicability of new technologies, namely Absorbed Natural Gas (ANG) and Natural Gas Hydrate (NGH) [31]. 


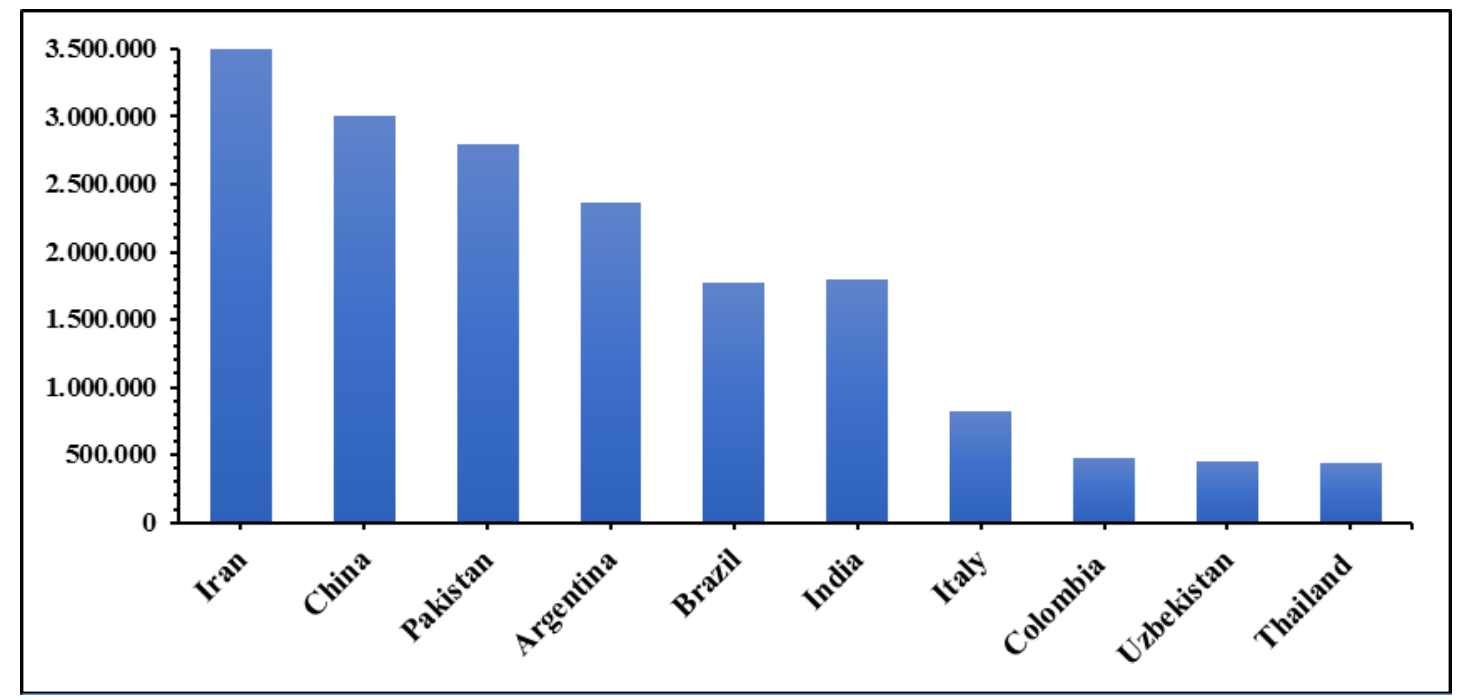

Fig. 5. The number of natural gas-powered vehicles by countries in 2014 [27].

Pipelines are the safest and most efficient way from production sources to demand center with respect to transportation in our globalized world. They, passing through Turkey, are of international vital significance because of the fact that Turkey is positioned at the meeting point of three continents (Asia, Europe and Africa) and therefore serves as a bridge between Asia and Europe accounting for well-nigh $67 \%$ of the world oil reserves and $40 \%$ of the world gas reserves [32]. Turkey supplies natural gas needs from various countries, which are Russian Federation, Iran, Nigeria, Algeria, Azerbaijan, Turkmenistan. While natural gas is supplied via pipelines from Russian Federation, Iran, Azerbaijan, and Turkmenistan, is supplied by tankers in its liquefied form [33].

Natural gas is transported by suitable pipe materials from the source to the consumer at appropriate pressure values. In the Blue Stream Project, the natural gas coming from Russia to Turkey through the Black Sea comes to Turkey within 12 hours with a pressure of 250 bar from Russia. BOTAS is responsible for the distribution of gas in Turkey. Natural gas comes from BOTAS through the RMS (Regulation Measuring Station), zone regulator and service box. Natural gas is transported between cities under high pressure (40-70 bar) through steel pipelines. It is reduced to 14-19 bar at the main pressure reduction stations near the city. This pressure is reduced to 4 bar at certain centers within the city. The natural gas at 4 bar pressure comes to the regulator stations at the residential entrances by way of polyethylene pipes; thus, the pressure is reduced to 21 mbar or to 300 mbar at large consumption points. These installations are carried out by the company which has got the city distribution contract.

\subsection{Existing natural gas pipelines in Turkey}

It is an obvious fact that Turkey has a growing importance that is growing rapidly in the energy sector. The developing economy and limited natural sources are increasing the energy import requirements of Turkey. Research studies carried out in 2015, report that the total length of natural gas pipeline was 13,276 km 12,963 and 313 $\mathrm{km}$ of which was constructed by BOTAS and TPAO companies, respectively, and natural gas supply is ensured to 74 cities.

It is planned to provide natural gas supply to all city centers with the completion of the transmission and distribution line projects which are still going on and will continue after 2015. Turkey currently imports 95-99\% of natural gas that it uses. A variety of natural gas producers in the world are making natural gas purchase agreements with countries. Turkey made the first agreement with the Soviet Union on September 18, 1984 for the supply of natural gas from abroad and has been importing $6 \mathrm{bcm}$ of natural gas per annum since 1987 [34]. The main countries with which Turkey has a natural gas agreement are shown in Table 1.

\subsubsection{Russia - Turkey west pipeline}

In September 1986, ENKA and its partner Spiecapag (France) signed an agreement with BOTAS for the supply of Russian gas pipeline. The $842 \mathrm{~km}$ long Russia-Turkey natural gas main transmission line enters Turkey at Malkoclar at the Bulgarian border and then follows Hamitabat, Ambarli, Istanbul, Izmit, Bursa, Eskisehir route to reach Ankara. Other major works in the agreement encompass $20 \mathrm{MW}$ compressor station, 11 reduction and metering stations, 9 pig stations, 32 line valves, dispatch centers, 3 maintenance centers, telecommunication and telecontrol systems. Natural gas supply capacity of the pipeline to Turkey through Ukraine has an annual $14 \mathrm{mcm}$ under a pressure of 70 bar. This is equal to nearly $75 \%$ of Turkey's current consumption. The project was funded by several export credit agencies such as US Exim, JEXIM, Coface, and ECGD. 
Table 1. International natural gas agreements of Turkey [35]

\begin{tabular}{|c|c|c|c|c|}
\hline Agreements & Amount (bcm/year) & Signed Date & Status & Expiration \\
\hline Algeria (LNG) & 4,4 & 1988 & In operation & October 2024 \\
\hline Nigeria (LNG) & 1,3 & 1995 & In operation & October 2021 \\
\hline Iran & 9,6 & 1996 & In operation & July 2026 \\
\hline Rus. Fed. (Blue Stream) & 16 & 1997 & In operation & End of 2025 \\
\hline Rus. Fed. (West) & 4 & 1998 & In operation & End of 2021 \\
\hline Turkmenistan & 15,6 & 1999 & - & April 2021 \\
\hline Azerbaijan (Stage-I) & 6,6 & 2001 & In operation & End of 2021 \\
\hline Greece & 0,75 & 2003 & In operation & 2018 \\
\hline Azerbaijan (Stage-II) & 0,15 & 2011 & & 2033 \\
\hline
\end{tabular}

\subsubsection{The Russian route pipeline connections (Blue Stream)}

Blue Stream project, which is the largest energy project ever applied so far, began with the Intergovernmental agreement signed on 15 December 1997 by Turkey and Russian Federation relating to the shipment of Russian natural gas from the Black Sea to the Republic of Turkey. The pipeline was constructed by the Blue Stream Pipeline B.V., the Netherlands based joint venture of Russian Gazprom and Italian Eni. According to the initial planning, the capacity of line was determined as $16 \mathrm{bcm}$. Blue Stream project, according to the agreement signed in 1997 by Moscow and Ankara for a 25-year period, foresees to import $16 \mathrm{bcm}$ of natural gas from Russia on a yearly basis. Approximately 380 kilometers of total 1213 kilometers long pipeline carrying natural gas passes under the Black Sea. Pipeline at the bottom of the sea is at the deepest point on Earth, a depth of 2150 meters. Gas transportation agreement officially entered into force on November 17, 2005 [36].

\subsubsection{Azerbaijan-Turkey pipeline (Shah Sea)}

BOTAS and SOCAR (State Oil Company of Azerbaijan) signed an agreement on March 12, 2001 with the intention of transporting natural gas produced in Azerbaijan to Turkey over Georgia. $1850 \mathrm{~km}$ long line starting from Turkgozu village of Ardahan provinence on Georgian border passes through 20 provinces, including Ardahan, Kars, Erzurum, Erzincan, Bayburt, Gumushane, Giresun, Sivas, Yozgat, Kirsehir, Kirikkale, Ankara, Eskisehir, Bilecik, Kutahya, Bursa, Balıkesir, Canakkale, Tekirdag, and Edirne coming to an end in Ipsala district of Edirne on the Greek border [37]. Shah Sea is a giant natural gas field located in the part of Azerbaijan of Caspian Sea. BP (British Petrol) is the main business area since it consists of seven different companies with $28.8 \%$ shareolder in a consortium. $6.6 \mathrm{bcm}$ of gas has been sold to Turkey from Stage 1 project of Shah Sea field since 2007. Development activities began after signed agreements in October 2011 concerning Shah Sea Stage 2 gas sales and transit passes between Azerbaijan and Turkey.

\subsubsection{Baku-Tbilisi-Erzurum pipeline (BTE)}

Baku-Tbilisi-Erzurum Pipeline is also known as South Caucasus Pipeline or BTE pipeline. BTE gas pipeline, which carries the gas produced from Shah Sea field located in the Caspian Sea of Azerbaijan, is $692 \mathrm{~km}$ in length and has a maximum capacity of $25 \mathrm{bcm}$ per annum. As a result of negotiations relating to the supply of gas from Azerbaijan, intergovernmental agreement between Azerbaijan and Turkey for the shipment of Azerbaijani gas to Turkey, and for importation of $6.6 \mathrm{bcm}$ of natural gas sale and purchase agreement was signed by SOCAR and BOTAS on March 12, 2001. The pipeline was constructed between 2005 and 2007, and has been operational since mid-July 2007. Increasing the capacity of portions between territories of Azerbaijan and Georgia in conjunction with production of the Stage 2 of Shah Sea field, BTE was planned to be linked to TransAnatolian gas pipeline project on December 17, 2003 [38].

\subsubsection{Iran - Turkey pipeline}

Natural gas taken from the sources in the East is intended to transport by pipeline to Turkey. Within this framework, natural gas sales and purchase agreement was signed with respect to $9.6 \mathrm{bcm}$ of import of natural gas by National Iranian Gas Company (NIGC) and BOTAS on August 8, 1996 for a 25-year period. Eastern Anatolia gas main transmission line, which provides an amount of $9.6 \mathrm{bcm}$ natural gas transmission from Iran to Turkey annualy, is about $1491 \mathrm{~km}$ in length. With the completion of the metering station in Bazargan (a city of Iran), natural gas supply from Iran began in December 10, 2001. According to the agreement, the gas flow started at $3 \mathrm{bcm} /$ year and reached $10 \mathrm{bcm} /$ year [39].

\subsubsection{Turkey - Greece pipeline}

Within the framework of European Commission INOGATE Program (Interstate Oil and Gas Transport to Europe), South European gas ring project has been developed involving interconnection of Turkey and Greece's natural gas network. Intergovernmental agreement relating to supply of natural gas was signed on February 23, 2003. After 
being put out to tender by BOTAS on November 25, 2004, natural gas network was started to be constructed in 2005 . When its construction was finished on November 17 2007, the total cost of 285-kilometer-long gas pipeline was around 250 million euro. A pipeline starting from Karacabey in Turkey, crossing the Marmara Sea with a distance of $17 \mathrm{~km}$, entering into Greece from Ipsala/Kipi border point and ending in Komotini was envisaged at the Desk Study [40].

\subsection{Pipeline projects - incoming pipelines to Turkey}

Since 2000, Turkey has been making very important contributions to projects that are closely followed on a global scale. Correspondingly, it has developed a multi-faceted energy policy and played an important role as a powerful regional actor in bringing the West and East together. The projects developed by Turkey are clarified in a comprehensible way below.

\subsubsection{Iraq-Turkey pipeline}

An integrated project involving field development, production, gas processing and pipeline construction for natural gas fields in Northern Iraq became a current issue with agreements signed by Iraq in 1996. BOTAS began talks with TPAO (Turkish State Petroleum Company) and Shell in the wake of new political developments that took place in Iraq in 2003. The project was named Iraq-Turkey Gas Export Project (ITGEP) by signing a Memorandum of Understanding among the three related above companies above mentioned in the business of natural gas export from Iraq to Turkey in 2008. Potential natural gas exploration and production opportunities for interested parties of Memorandum of Understanding as well as possible links to neighboring countries will form a framework for assessing the natural gas infrastructure in Turkey, and exporting the increased natural gas to Turkey and Europe after negotiating by the internal demands of countries like Iran.

Memorandum of Understanding was signed with respect to the development of natural gas corridor by the Ministry of Energy and Natural Resources and the Iraqi Petroleum Ministry on October 15, 2009. Memorandum of Understanding aims to improve natural gas corridor between the two countries through transport of Iranian natural gas to Turkey and Europe via Turkey [41].

\subsubsection{Egypt - Turkey pipeline}

Egypt-Turkey natural gas pipeline is also known as Arabian natural gas pipeline. It is a project that emerged after the cancellation of the LNG (Liquefied Natural Gas) project initiated in 1996, resulting from the transfer of $10 \mathrm{bcm}$ of gas from Egypt's pipeline to the Mediterranean Sea. Memorandum of Understanding regarding imports of natural gas from Egypt to Turkey was signed by the Ministry of Energy and Natural Resources and the Egyptian Petroleum Ministry on June 22, 1998.

A framework Agreement was signed by Turkey and Egypt on March 17, 2004 in Cairo, for the import of natural gas by BOTAS from Egypt Natural Gas Company EGAS and the transit of gas from Egypt to Europe through Turkey. One part of the Arabian natural gas pipeline has been completed and Egyptian gas is currently being provided to Jordan, Syria and Lebanon. When the project is utterly completed for Turkey, Egyptian gas can be an alternative to Russian and Iranian gas. In fact, according to some experts, Egyptian natural gas can be a balancer rather than an alternative, and it should be added to other Arab countries [42].

\subsubsection{Transcaspian Turkmenistan-Turkey-Europe pipeline}

Natural gas, which is produced in the fields situated in the south of Turkmenistan with Turkmenistan- TurkeyEurope natural gas pipeline project, is intended to be transported to Turkey and to Europe via Turkey with TransCaspian gas pipeline. In the context of negotiations, a framework agreement was signed by the Heads of State of Turkey and Turkmenistan in 1998 towards the realization of this project. In accordance with this mutual agreement, Turkmenistan has a total gas of $30 \mathrm{bcm}, 16 \mathrm{bcm}$ and $14 \mathrm{bcm}$ all of which will be transported to Turkey and Europe, respectively. A natural gas sale and purchase agreement valid for 30 years was signed on May 21, 1999 by BOTAS and the authorized body for the use of Hydrocarbon Resources of the President of Turkmenistan [43].

\subsubsection{Interconnector Turkey-Greece-Italy (ITGI)}

Turkey-Greece natural gas pipeline (ITGI) constitutes the first ring of South European gas ring. Intergovernmental agreement of the project was signed in Rome in 2007 by the ministers of countries responsible for energy projects, and it is known as the important projects that will supply natural gas. Intercompany Memorandum of Understanding was signed by BOTAS, DEPA (Public Natural Gas Supply Corporation of Greece) and EDISON (Italian Energy Company) by the General Managers of these companies on June 17, 2010.

Onshore part of the project is $592 \mathrm{~km}$ from Komotini (a city in the region of East Macedonia and Thrace) to Adriatic coast, $212 \mathrm{~km}$ of which is sea crossing section. Besides this, the maximum depth is estimated to be $1450 \mathrm{~m}$. Within the scope of the project, a total of $11.6 \mathrm{bcm} /$ year gas are planned to be transported through Turkey in the plateau level, $3.6 \mathrm{bcm} /$ year for Greece and $8 \mathrm{bcm} /$ year for Italy of which are supplied from Caspian sources [44].

\subsubsection{Trans-Anatolian pipeline (TANAP)}

The plan in this pipeline project which is planned to be transferred Azerbaijan natural gas to Europe through Turkey. The main aim of the project was to constitute Southern gas corridor by merging with South Caucasus pipeline (SCP) and Trans Adriatic pipeline (TAP). The seeds of the project were planted at the 3rd Blach sea Energy and Economic Forum organized in Istanbul on November, 2011. After a short time, Intergovernmental Memorandum of Understanding was signed by Ministers responsible for energy of the two 
countries in Ankara / Turkey on December 24, 2011. After negotiations, an agreement was signed among BP, BOTAS and SOCAR in 2015. The TANAP project is carried out by a consortium led by the SOCAR. The project has a share of SOCAR with $58 \%$, BOTAS with $30 \%$, and BP with $12 \%$.

When its construction is completed, it is intended to be used for the transfer of natural gas extracted from Shah Sea gas facilities. The main line encloses a total of $1850 \mathrm{~km}, 19$ $\mathrm{km}$ of which is Marmara Sea crossing. Furthermore, the number and qualifications to be used in the operation of the connection lines in the exit points in Turkey, comprise of above-ground facilities including 7 compressor stations, 4 metering stations, 11 pig stations, 49 block valve stations, and 2 gas outputs to feed into the national gas station network in Turkey.

Within the scope of Shah Sea Stage II, the first step of the line capacity is targeted to be $16 \mathrm{bcm}$ annually, $6 \mathrm{bcm}$ of which will be sold to the Turkish domestic market and the remaining $10 \mathrm{bcm}$ portion will be exported to the European markets. It is expected that the gas will reach Turkey between 2018 and 2020. The capacity of the line has been targeted to reach $16 \mathrm{bcm}$ in 2020, $23 \mathrm{bcm}$ in 2023 and 31 bcm in 2026 [45].

\subsubsection{The Nabucco west pipeline}

Treaty of the Nabucco West was signed in Vienna with the participation of BOTAS from Turkey on October 11, 2002. The Nabucco pipeline was accelerated with agreement signed by the governments on July 13, 2009. The project was planned to transport natural gas to the EU via Turkey. The main purpose of the project is to supply natural gas by means of Trans-Anatolian gas pipeline project from Shah Sea gas field of West to Europe. The line is also considered to be a part of the EU's Trans-European energy line, and benefited from EU funding for feasibility and engineering studies. According to preliminary calculations, the total cost of the project would be in the range between 4 and 6 billion euro. Thanks to the 1320-kilometer line, $20 \mathrm{bcm}$ of gas would be transported to Central Europe; despite mutual agreements between two countries, the project was officially cancelled in 2013 as a result of disputes [46].

\subsubsection{Russia-Turkey-Europe natural gas pipeline (Turkish Stream)}

Turkish Stream is the name of the natural gas pipeline project that was planned to transfer from Russia and natural gas to Turkey via the Black Sea. An intergovernmental agreement was signed for the Turkish stream natural gas pipeline project in October 10, 2016. Even though the starting point of the pipeline was determined as the Russkaya compressor station near Anapa, there is no official information on where it would enter Turkey. When the starting point in Turkey is determined, it is expected that Gazprom (a large Russian company) will start works on pipe-laying immediately. The construction of 4 submarine pipelines is planned. In addition, within the scope of the ongoing technical work, a maximum of $63 \mathrm{bcm}$ natural gas has been considered to be transported on annual basis. It is thought that Turkey will supply about $14 \mathrm{bcm}$ of natural gas per year from this project and the remaining $49 \mathrm{bcm}$ of natural gas will be exported to Europe [47].

\subsubsection{Trans adriatic natural gas pipeline (TAP)}

After the Nabucco West project was called off, it was replaced by TAP project. It is a natural gas pipeline project initiated by connecting to TANAP in Turkey / Ipsala, with $478 \mathrm{~km}$ pipeline from Northern Greece, passing through Albania and then under the Adriatic Sea. The agreement of the project was signed by Shah Sea Consortium on September 19, 2013, and an investment of 35 billion dollars was foreseen. As soon as the construction of the pipeline can be completed at the beginning of 2018, after a very short time from this date, flow of natural gas will put into operation [48, 49].

\section{Liquefied Natural Gas (LNG) Transportation}

Natural gas is transported by ships when it is not possible to transport through pipelines. In this case, the volume of natural gas is reduced 600 times by refrigerating well below $163{ }^{\circ} \mathrm{C}$ and increasing its pressure. LNG is cleaner when compared to natural gas, because contaminants are eradicated during liquefaction. It is then transported by ships equipped with a special way through the methane tanker. The $2000 \mathrm{~km}$ long pipeline connecting to Germany natural gas extracted from North Sea is the world's longest natural gas submarine pipeline.

The Government of the Republic of Turkey decided to import $4 \mathrm{bcm}$ of LNG from Algeria with an agreement signed in 1995 for a 26-year period and $12 \mathrm{bcm}$ of LNG from Nigeria with an agreement signed in 1988 for a 36-year period by reason of diversification of supply sources and balance of seasonal burden [50]. Marmara Eregli LNG Terminal, which is located in an area of 66 hectares, was built between 1989 and 1994. Turkey's second LNG terminal, which was commissioned in the winter of 2006, is situated in Aliaga/Izmir [51].

\section{Compressed Natural Gas (CNG) Transportation}

Compressors are compressed at a pressure of 206 bar in order to increase the energy density of natural gas, called Compressed Natural Gas (CNG). It is one of the energy types that are likely to become the future fuel. In addition to being used as fuel in vehicles, it meets the needs of consumers by transporting through articulated lorry and special truck in places where the natural gas pipelines are not accessible or reachable. For instance, most of the People's Republic of China's natural gas needs are met by CNG system, and even in Italy, where natural gas pipelines are very common, CNG system is utilized in industrial cities like Genova. In Europe, unlike Italy, it is employed in many countries such as Germany, Holland, France, Austria, Switzerland [52, 53]

Considering that the damage petroleum products used in mass transportation vehicles have given to the environment, 
it may be possible to use natural gas as an alternative fuel. The quick increase in the use of individual vehicles, especially in recent years, has accelerated the trend towards more economical alternative fuels and as a result of investments of R \& D companies in this area have started to enhance gradually [54-56].

\section{Conclusion}

The history of natural gas, which is one of the biggest energy sources of our era, dates back hundreds of years. Statement of the "Sacred Fire" has been used throughout the humanity history. For the first time, natural gas utilized as an energy source by Chinese for the salt-drying process has been employed. Subsequently, they transported natural gas to other places by means of hollowed bamboos. Thus, natural gas has begun to spread rapidly in an important manner. It varies depending on usage have been adopted by the majority of people and has expanded gradually for many years over the large parts of the world.

In recent years, especially in the last two decades, the use of natural gas in electricity generation and housing has increased enormously, and the share of natural gas in the developing countries will increase by $4 \%$ per annum by 2030 , the share of primary energy resources on natural gas will rise by $23 \%$. The consumption of countries will enhance by $1.3 \%$ per annum on average, and the augmentation in energy sources and the environment will be decisive.

It will be the most used fossil fuel in the future because of the constant evolution of natural gas and the low carbon emissions it releases. Increasing demand for energy and petroleum expectations indicate that natural gas will be an advantageous position in the future. The development of natural gas in the world is expected to continue with the strengthening of both political and commercial and environmental effects.

\section{References}

[1] J. A. Fagerstrom, "The evolution of reef communities", 1987.

[2] İ. Atılgan, "Türkiye'nin enerji potansiyeline bakış", Gazi Üniversitesi Mühendislik-Mimarlık Fakültesi Dergisi, vol. 15,2000 .

[3] S. Shafiee and E. Topal, "When will fossil fuel reserves be diminished?", Energy policy, vol. 37, pp. 181-189, 2009.

[4] N. H. Afgan, P. A. Pilavachi, and M. G. Carvalho, "Multi-criteria evaluation of natural gas resources", Energy Policy, vol. 35, pp. 704-713, 2007.

[5] BP Statistical Review of World Energy. BP p.l.c, London, United Kingdom, 64th edition, 2015.
[6] R. W. Howarth, A. Ingraffea, and T. Engelder, "Natural gas: Should fracking stop?", Nature, vol. 477, pp. 271-275, 2011.

[7] R. Heinberg and D. Fridley, "The end of cheap coal", Nature, vol. 468, pp. 367-369, 2010.

[8] M. R. Tek, "Underground storage of natural gas: theory and practice", Springer Science \& Business Media, vol. 171, 2012.

[9] N. A. Afgan, P. A. Pilavachi, and M. G. Carvalho, "Multi-criteria evaluation of natural gas resources", Energy Policy, vol. 35, pp. 704-713, 2007

[10] M. Balat, "Oil and natural gas transport systems, trade and consumption trends in Turkey", Energy exploration \& exploitation, vol. 22, pp. 207-216, 2004.

[11] M. Balat, G. Ayar, C. Oguzhan and H. Uluduz, Influence of fossil energy applications on environmental pollution, Energy Source, Part B, vol. 2, pp. 213-226, 2007.

[12] T. Colborn, C. Kwiatkowski, K. Schultz \& Bachran, "Natural gas operations from a public health perspective", Human and ecological risk assessment: An International Journal, vol. 17, pp. 1039-1056, 2011.

[13] K. Bilen, O. Ozyurt, K. Bakirci, S. Karsli, S. Erdogan, M. Yilmaz and O. Comakli Energy production, consumption, and environmental pollution for sustainable development: A case study in Turkey, Renewable and Sustainable Energy Reviews, vol. 12, pp. 1529-1561, 2008.

[14] T.M. Verhallen and W. Fred Van Raaij, "Household behavior and the use of natural gas for home heating", Journal of Consumer Research, vol. 8.3, pp. 253-257, 1981.

[15] A. Demirbas, "The importance of natural gas as a world fuel", Energy Sources, Part B, vol. 1, pp. 413-420, 2006.

[16] M. Balat, "World natural gas (NG) reserves, NG production and consumption trends and future appearance", Energy sources, vol. 27, pp. 921-929, 2005.

[17] C. S. Weaver, Natural gas vehicles-A review of the state of the art. No. 892133. SAE Technical Paper, 1989.

[18] M. Ergeneman, C. Sorusbay, and A. G. Goktan, Exhaust emission and fuel consumption of $\mathrm{CNG} /$ diesel fueled city buses calculated using a sample driving cycle. Energy Sources, vol. 21, pp. 257-268, 1999.

[19] H. Engerer and M. Horn, "Natural gas vehicles: An option for Europe." Energy Policy, vol. 38, pp. 1017-1029, 2010.

[20] N.O. Nylund \& A. Lawson, "Exhaust emissions from natural gas vehicles", Issues related to engine performance, 
exhaust emissions and environmental impacts, IANGV Emission Report, 2000.

[21] H. Engerer \& M. Horn, "Natural gas vehicles: An option for Europe", Energy Policy, vol. 38, pp. 1017-1029, 2010.

[22] S. Yeh, "An empirical analysis on the adoption of alternative fuel vehicles: the case of natural gas vehicles", Energy Policy, vol. 35, pp. 5865-5875, 2007.

[23] A. Janssen, S. F. Lienin, F. Gassmann \& A. Wokaun, "Model aided policy development for the market penetration of natural gas vehicles in Switzerland", Transportation Research Part A: Policy and Practice, vol. 40, pp. 316-333, 2006.

[24] P. C. Flynn, "Commercializing an alternate vehicle fuel: lessons learned from natural gas for vehicles", Energy Policy, vol. 30, pp. 613-619, 2002.

[25] M. P. Hekkert, F. H. Hendriks, A. P. Faaij \& M. L. Neelis, "Natural gas as an alternative to crude oil in automotive fuel chains well-to-wheel analysis and transition strategy development", Energy policy, vol. 33, pp. 579-594, 2005.

[26] A. H. Kakaee \& A. Paykani, "Research and development of natural-gas fueled engines in Iran", Renewable and Sustainable Energy Reviews, vol. 26, pp. 805-821, 2013.

[27] M. Matsumoto, S. Kondoh, J. Fujimoto, Y. Umeda, H. Tsuchiya, K. Masui \& H. Y. Lee, "A diffusion model for clean energy vehicles." Journal of Japan Society of Energy and Resources, vol. 29, pp. 49-55, 2008.

[28] B. Singh, A. H. Strømman \& E. Hertwich, "Life cycle assessment of natural gas combined cycle power plant with post-combustion carbon capture, transport and storage", International Journal of Greenhouse Gas Control, vol. 5, pp. 457-466, 2011.

[29] P. A. Pilavachi, S. D. Stephanidis, V. A. Pappas \& N. H. Afgan, "Multi-criteria evaluation of hydrogen and natural gas fuelled power plant technologies", Applied Thermal Engineering, vol. 29, pp. 2228-2234, 2009.

[30] B. Atilgan \& A. Azapagic, "Life cycle environmental impacts of electricity from fossil fuels in Turkey", Journal of Cleaner Production, vol. 106, pp. 555-564, 2015.

[31] S. Mokhatab \& W. A. Poe, "Handbook of natural gas transmission and processing. Gulf Professional Publishing", 2012.

[32] S. E. Masten \& K. J. Crocker, "Efficient adaptation in long-term contracts: Take-or-pay provisions for natural gas", The American Economic Review, vol. 75, pp. 1083-1093, 1985 .
[33] M. Balat \& N. Ozdemir, "Turkey's oil and natural gas pipelines system", Energy sources, vol. 27, pp. 963-972, 2005.

[34] H. K. Ozturk \& A. Hepbasli, "The place of natural gas in Turkey's energy sources and future perspectives", Energy Sources, vol. 25, pp. 293-307, 2003.

[35] BOTAS, Petroleum Pipeline Corporation, 2015, http://www.botas.gov.tr/

[36] G. Bacik, "The Blue Stream project, energy cooperation and conflicting interests", Turkish Studies, vol. 2, pp. 85-93, 2001.

[37] K. Barysch, "Should the Nabucco pipeline project be shelved?", Centre for European Reform, 2010.

[38] T. Babali, "Implications of the Baku-Tbilisi-Ceyhan main oil pipeline project", Perceptions, Journal of International Affairs (Center for Strategic Research by the Ministry of Foreign Affairs, Turkey), vol. 10, pp. 29-59, 2005.

[39] G. Bacik, "Turkey and pipeline politics", Turkish Studies, vol. 7, pp. 293-306, 2006.

[40] G. M. Winrow, "Turkey and the East-West Gas Transportation Corridor", Turkish Studies, vol. 5, pp. 23-42, 2004.

[41] H. J. Barkey, "Turkey and Iraq: The making of a partnership", Turkish Studies, vol. 12, pp. 663-674, 2011.

[42] A. M. Kilic, "Major utilization of natural gas in Turkey", Energy exploration \& exploitation, vol. 23, pp. 125140, 2005.

[43] H. K. Ozturk \& Arif Hepbasli, "Natural gas implementation in Turkey. Part 2: Natural gas pipeline projects", Energy sources, vol. 26, pp. 287-297, 2004.

[44] C. Üstün, "Energy Cooperation between Import Dependent Countries: Cases of Italy and Turkey", Perceptions, vol. 16, pp. 71, 2011.

[45] G. M. Winrow, "The southern gas corridor and Turkey's role as an energy transit state and energy hub", Insight Turkey, vol. 15, pp. 145, 2013.

[46] A. Sobjak \& K. Zasztowt, "Nabucco WestPerspectives and Relevance: The Reconfigured Scenario", PISM policy paper, pp. 44, 2012.

[47] M. Hafner \& S. Tagliapietra, "Turkish Stream: What Strategy for Europe?", 2015.

[48] N. Sartori, "Energy and politics: behind the scenes of the Nabucco-TAP competition", IAI WP , vol. 13, pp. 27, 2013. 
[49] M. MacDonald, "Supplying the EU natural gas market", November, Final Report, Croydo, the United Kingdom, 2010 .

[50] J. J. Zednik, D. L. Dunlavy \& T. G. Scott, "Regasification of liquefied natural gas (LNG) aboard a transport vessel", U.S. Patent No. 6,089,022. 18 Jul. 2000.

[51] B. Kavalov, H. Petric \& A. Georgakaki, "Liquefied natural gas for Europe-some important issues for consideration", Joint Research Centre of the European Commission Reference Report, 2009.

[52] A. Demirbas, "Fuel properties of hydrogen, liquefied petroleum gas (LPG), and compressed natural gas (CNG) for transportation", Energy Sources, vol. 24, pp. 601-610, 2002.
[53] S. Thomas \& R. A. Dawe, "Review of ways to transport natural gas energy from countries which do not need the gas for domestic use", Energy, vol. 28, pp. 1461-1477, 2003.

[54] J. Ally \& T. Pryor, "Life-cycle assessment of diesel, natural gas and hydrogen fuel cell bus transportation systems", Journal of Power Sources, vol. 170, pp. 401-411, 2007.

[55] M. J. Economides, K. Sun \& G. Subero, "Compressed natural gas (CNG): an alternative to liquefied natural gas (LNG)", SPE Production \& Operations, vol. 21, pp. 318-324, 2006.

[56] R. A. B. Semin, "A technical review of compressed natural gas as an alternative fuel for internal combustion engines", Am. J. Eng. Appl. Sci, vol. 1, pp. 302-311, 2008. 